\title{
Penerapan Layanan Bimbingan Kelompok Untuk Mengubah Persepsi Negatif Terhadap BK Pada Siswa Kelas VII Semester 2 Tahun Pelajaran 2015/2016 di MTs Negeri III Surabaya
}

\author{
Siti Ma'rifah Setiawati \\ Guru Bimbingan Dan Konseling MTsN 4 Surabaya \\ Enail: marifah0404@gmail.com
}

\begin{abstract}
Abstrak
Penelitian ini bertujuan untuk mengubah persepsi negatif siswa terhadap peran BK dengan menerapkan layanan bimbingan kelompok. Variabel-variabel penelitiannya terdiri dari persepsi siswa dan peran Bimbingan Konseling di sekolah. Penelitian ini dilakukan pada bulan Januari sampai dengan April 2016, sampel penelitian adalah siswa kelas VII D MTs Negeri III Surabaya yang terdiri dari 36 orang peserta didik dengan komposisi 22 orang perempuan dan 14 orang laki-laki. Penelitian ini menggunakan pendekatan kualitatif. Data penelitian dikumpulkan dengan menggunakan catatan lapangan, observasi, wawancara, dan dokumentasi. Kriteria keberhasilan penelitian ini, jika jumlah siswa yang datang minimal $50 \%$ dari jumlah siswa di kelas VII D (36 siswa $\times 50 \%=18$ siswa) dalam setiap bulan dan akan menjadi lebih baik jika dapat mempengaruhi siswa yang lain sehingga dengan senang hati datang ke ruang BK. Hasil penelitian ditunjukkan dengan data kunjungan siswa dimana siswa yang datang ke ruang BK selama bulan Pebruari ada 4 siswa kelas VII D yang datang ke ruang BK dan ada 4 siswa yang berkirim surat serta ada 4 siswa dari kelas lain yang datang ke ruang $B K$, dan di bulan maret ada 25 siswa kelas VII D yang datang ke ruang BK dan ada 29 siswa yang berkirim surat serta ada 45 siswa yang datang ke ruang BK sedangkan targetnya minimal $50 \%$ dari jumlah siswa kelas VII D $(50 \%$ × 36 siswa $=18$ siswa $)$.
\end{abstract}

Kata kunci : Peran Bimbingan Konseling di sekolah, persepsi siswa terhadap Bimbingan Konseling. 


\section{PENDAHULUAN}

Bimbingan dan Konseling telah dimasukkan dalam kurikulum SLTP dan SMU sejak tahun 1975, 1984, dan 1994 diseluruh Indonesia. Berdasarkan Surat Keputusan Bersama Menteri Pendidikan dan Kebudayaan dan Kepala Badan Administrasi Kepegawaian Negara Nomor : 0433/P/1993 dan Nomor 25 Tahun 1991 diharapkan pada setiap sekolah ada petugas yang melaksanakan layanan bimbingan yaitu guru pembimbing atau konselor dengan rasio satu orang guru pembimbing atau konselor untuk 150 orang siswa (Sukardi,2000). Berdasarkan Pasal 27 Peraturan Pemerintah Nomor 29/90 dinyatakan bahwa Bimbingan merupakan bantuan yang diberikan kepada siswa dalam rangka upaya menemukan pribadi, mengenal lingkungan, dan merencanakan masa depan (Sukardi,2000), sedangkan konseling merupakan salah satu jenis layanan yang merupakan bagian terpadu dari bimbingan. Konseling dapat diartikan sebagai hubungan timbal balik antara dua individu, yang seorang yaitu konselor berusaha membantu yang lain yaitu klien untuk mencapai pengertian tentang dirinya sendiri dalam hubungan dengan masalahmasalah yang di hadapinya pada waktu yang akan datang (Natawidjaja,1987).

Layanan bimbingan konseling seharusnya direspon positif dan disambut baik oleh siswa atau dimanfaatkan keberadaannya, karena layanan tersebut sangat menguntungkan dan dapat membantu siswa di dalam menyelesaikan masalah-masalah yang dialami, namun pada kenyataanya kebanyakan siswa merespon negatif atau kurang memanfaatkannya keberadaan layanan bimbingan konseling, dengan kata lain siswa belum berminat menyelesaikan permasalahan yang dihadapi melalui layanan bimbingan konseling yang disediakan di sekolah, bahkan ada persepsi bahwa siswa yang dipanggil atau datang ke ruang BK adalah siswa yang bermasalah.

Layanan bimbingan konseling seharusnya direspon positif dan disambut baik oleh siswa atau dimanfaatkan keberadaannya, karena layanan tersebut sangat 
menguntungkan dan dapat membantu siswa di dalam menyelesaikan masalah-masalah yang dialami, namun pada kenyataanya kebanyakan siswa merespon negatif atau kurang memanfaatkannya keberadaan layanan bimbingan konseling, dengan kata lain siswa belum berminat menyelesaikan permasalahan yang dihadapi melalui layanan bimbingan konseling yang disediakan di sekolah, karena ada persepsi bahwa siswa yang dipanggil atau datang ke ruang BK adalah siswa yang bermasalah yang perlu diberi sanksi.

Selama ini yang datang berkunjung ke BK hanya karena di panggil BK atau hasil kiriman dari guru mapel atau wali kelasnya.

Adapun data siswa yang ke ruang BK karena dipanggil selama bulan Januari 2016 adalah sebagai berikut :

\begin{tabular}{|c|c|c|c|}
\hline NO & KELAS & JUMLAH & MASALAH \\
\hline 1 & VII & 36 & Tatib \\
\hline 2 & VIII & 0 & Tatib \\
\hline 3 & IX & 41 & Tatib \\
\hline
\end{tabular}

Hal ini terjadi karena selama ini Bimbingan Konseling hanya dikenal sebagai "Polisi Sekolah", maka banyak siswa takut untuk datang ke Bimbingan Konseling.

Berdasarkan hal tersebut diatas maka kami mengadakan Penelitian Tindakan Bimbingan Konseling tentang "Penerapan Layanan Bimbingan Kelompok Untuk Mengubah Persepsi Negatif Terhadap BK Pada Siswa Kelas VII Semester 2 Tahun Pelajaran 2015/2016 di MTs Negeri III Surabaya".

Dilihat dari tujuan BK sebenarnya BK adalah tempat yang tiap hari akan dikunjungi oleh para siswa, BK adalah tempat yang menyenangkan, namun kenyataannya malah sebaliknya. Siswa datang ke BK karena dipanggil, siswa datang ke BK karena ada masalah tata tertib, dan kebanyakan masalah yang ditangani BK adalah masalah pelanggaran tata tertib sekolah, sedangkan masalah pribadi, sosial, keluarga sangat jarang sekali. Hal ini menunjukkan bahwa BK hanya tempat penyelesaian para "kriminal" sekolah. Harapannya dengan adanya penerapan layanan kelompok ini dapat meningkatkan jumlah siswa yang berkunjung ke BK atau yang berkirim surat ke BK minimal $50 \%$ 
dari jumlah siswa kelas VII D dan akan menjadi lebih baik jika membawa pengaruh bagi kelas lain untuk datang ke ruang BK dengan senang hati tanpa menunggu dipanggil dulu baik oleh guru BK, maupun oleh guru mapel yang lain.

Bimbingan mengandung layanan kepada siapa saja yang membutuhkan bantuan dan kepada siapa saja yang dapat dibantu. Bimbingan, tegasnya, merupakan bantuan yang diberikan oleh seseorang kepada orang lain sehubungan dengan kegiatan dalam membuat pilihan, sehubungan dengan kegiatan penyesuaian. Dapat pula sehubungan dengan kegiatan dalam memecahkan masalah atau kesulitan. Tujuannya supaya orang yang dibantu atau dibimbing dapat meningkatkan derajat kemandiriannya dan meningkatkan kecakapannya.

Ada beberapa ahli yang berpendapat mengenai bimbingan. Menurut Dr Najlatun Naqiyah (2012) bimbingan adalah bantuan yang diberikan agar individu memiliki pilihan dan alternatif yang bijaksana untuk memutuskan perbuatan yang akan dipilihnya. Karena setiap manusia akan memilih pilihan yang perlu dipertimbangkn secara rasional. Bimbingan akan memberikan manfaat bagi individu untuk melakukan anlisis diri akan pengalaman, pengetahuan, ketrampilanyang dimiliki dan perlu dikembangkan untuk mencapai pekembangan individu yang optimal. Bimbingan adalah usaha membantu individu untuk memberikan informasi pengetahuan, pengalaman, ketrampilan, sikap yang akan berfungsi pada pengembangan diri individu.

Natawidjaya (dalam Sukardi, 2000) menyatakan bahwa bimbingan dapat diartikan sebagai suatu proses pemberian bantuan kepada individu yang dilakukan secara berkesinambungan supaya individu tersebut dapat memahami dirinya sendiri, sehingga sanggup mengarahkan dirinya dan dapat bertindak secara wajar, sesuai dengan tuntutan dan keadaan lingkungan sekolah, keluarga, dan masyarakat serta kehidupan pada umumnya. Ditambahkan oleh Surya (dalam Sukardi, 2000) bahwa bimbingan ialah suatu proses pemberian bantuan 
yang terus menerus dan sistematis dari pembimbing kepada yang dibimbing agar tercapai kemandirian dalam pemahaman diri dan perwujudan diri, dalam mencapai tingkat perkembangan yang optimal dan penyesuaian diri dengan lingkungannya.

Prayitno (dalam Sukardi, 2000) juga menambahkan bahwa bimbingan merupakan bantuan yang diberikan kepada seseorang (individu) atau sekelompok orang agar dapat berkembang menjadi pribadi-pribadi yang mandiri. kemandirian ini mencakup lima fungsi pokok yang hendaknya dijalankan oleh pribadi mandiri, yaitu mengenal diri sendiri dan lingkungannya, menerima diri sendiri dan lingkungan secara positif dan dinamis, mengambil keputusan, mengarahkan diri sendiri, dan mewujudkan diri mandiri.

Konseling sebagai terjemahan dari Counseling merupakan bagian dari bimbingan, baik sebagai layanan maupun sebagai teknik. Layanan konseling adalah jantung hati layanan bimbingan secara keseluruhan. Jadi konseling merupakan inti dari alat yang paling penting dalam bimbingan. Rogers (dalam Latipun, 2001) berpendapat bahwa konseling merupakan hubungan terapi dengan klien yang bertujuan untuk melakukan perubahan diri pada pihak klien. Sedangkan menurut Pietrosa (dalam Latipun, 2001) konseling adalah proses yang melibatkan seseorang professional berusaha membantu orang lain dalam mencapai pemahaman dirinya, membuat keputusan dan pemecahan masalah.

Natawidjaya (dalam Sukardi, 2000) mendefinisikan konseling sebagai satu jenis layanan yang merupakan bagian terpadu dari bimbingan. Konseling dapat diartikan sebagai hubungan timbal balik antara dua individu, yang seorang (yaitu konselor) berusaha membantu yang lain (yaitu klien) untuk mencapai pengertian tentang dirinya sendiri dalam hubungan dengan masalahmasalah yang dihadapinya pada waktu yang akan datang. Surya (dalam Sukardi, 2000) mengungkapkan bahwa konseling itu merupakan upaya bantuan yang diberikan kepada konseli supaya memperoleh konsep diri dan kepercayaan diri sendiri, untuk 
dimanfaatkan dalam memperbaiki tingkah laku pada masa yang akan datang. Lebih lanjut Prayitno (dalam Sukardi, 2000) mengemukakan bahwa konseling adalah pertemuan empat mata antara klien dengan konselor yang berisi usaha yang laras, human (manusiawi), yang dilakukan dalam suasana keahlian berdasarkan atas norma-norma yang berlaku.

Kehidupan individu tidak dapat lepas dari lingkungan baik lingkungan fisik maupun sosial, dimana setiap individu menerima langsung stimulus atau rangsangan dari luar dirinya. Dalam rangka individu mengenali stimulus merupakan persoalan yang berkaitan dengan persepsi.

Persepsi merupakan masalah yang penting dalam lapangan ilmu psikologi, terutama bila dilihat dari segi pentingnya masalah persepsi dalam kehidupan sehari-hari. Tiaptiap individu mempunyai persepsi yang berbeda-beda, walaupun individu tersebut menerima stimulus yang obyeknya sama. Dengan mengetahui persepsi seseorang maka akan diperoleh gambaran kemungkinan tentang bagaimana individu memberikan respon terhadap suatu obyek atau keadaan yang dihadapinya.

Persepsi mempunyai pengertian yang bervariasi dari setiap ahli.menurut Branca, Woodworth, dan Marquis, (dalam walgito, 1997 ) persepsi merupakan suatu proses yang didahului oleh penginderaan, penginderaan merupakan suatu proses diterimanya stimulus oleh individu melalui alat indera yang diteruskan oleh syaraf ke otak sebagai pusat susunan syaraf dan selanjutnya merupakan proses persepsi.. Simulus yang diindera itu oleh individu diorganisasikan, kemudian diinterpretasikan, sehingga individu menyadari, mengerti tentang apa yang diindra itu, inilah yang disebut persepsi menurut Davidoff (dalam Walgito, 1997). Rahmat (1999), Menambakan persepsi adalah pengalaman tentang obyek, peristiwa, atau hubungan-hubungan yang diperoleh dengan menyimpulkan informasi dan menafsirkan pesan. persepsi merupakan keadaan yang integrated dari individu terhadap stimulus yang diterimanya. Karena merupakan keadaan yang integrated 
dari individu yang bersangkutan, maka apa yang ada dalam diri individu, pengalaman-pengalaman individu, akan ikut aktif dalam persepsi tersebut Moskowits, dan Orgel, (dalam Walgito, 1997). Berdasarkan beberapa definisi persepsi di atas dapat disimpulkan bahwa persepsi adalah gambaran atau pengalaman individu tentang suatu obyek, peristiwa atau keadaan sehingga individu memberikan respon terhadap obyek atau keadaan yang dihadapinya.

Menurut Walgito (1997), proses terjadinya persepsi adalah obyek menimbulkan stimulus, dan stimulus mengenai alat indera atau reseptor. Proses ini dinamakan proses kealaman (fisik). Stimulus yang diterima oleh alat indera dilanjutkan oleh syaraf sensoris ke otak. Proses ini dinamakan proses fisiologis. Kemudian terjadilah suatu proses di otak, sehingga individu dapat menyadari apa yang di terima dengan reseptor itu, sebagai suatu akibat dari stimulus yang diterimanya. Proses yang terjadi dalam otak atau pusat pusat kesadaran itulah yang dinamakan proses psikologis. Dengan demikian taraf terakhir dari prosess persepsi ialah individu menyadari tentang apa yang diterima melalui alat indera atau reseptor. Proses ini merupakan proses terakhir dari persepsi dan merupakan persepsi yang sebenarnya. Respon sebagai akibat dari persepsi dapat diambil oleh individu dalam berbagai macam bentuk.

Keadaan menunjukkan bahwa individu tidak hanya dikenai oleh satu stimulus melainkan individu dikenai oleh bermacam-macam stimulus yang ditimbulkan oleh keadaan sekitar. Tetapi tidak semua stimulus itu mendapatkan respon, hanya stimulus yang menarik perhatian yang diberikan respon. Individu yang mengadakan seleksi stimulus mana yang akan diberikan respon, sebagai akibat dari stimulus yang dipilih oleh individu. Individu tersebut akan menyadari dan memberikan reaksi.

Adanya obyek yang diamati dan alat indera yang baik serta perhatian, merupakan syarat terjadinya persepsi. individu akan mempersepsikan sesuatu karena ada yang diamati, dengan demikian individu tersebut akan memusatkan pikirannya untuk 
memperhatikan sesuatu, demikian juga dengan layanan bimbingan konseling yang diselenggarakan oleh sekolah .

Siswa sebagai subyek didik dan secara umum sebagai manusia tidak akan lepas dari masalah. Dengan adanya layanan bimbingan konseling ini maka siswa dapat memanfaatkannya untuk meringankan beban masalahnya. Sebagai siswa remaja dan memasuki masa dewasa, dalam membicarakan masalahnya kadang-kadang kurang puas untuk berbicara secara pribadi dengan orang tuanya, namun siswa ingin sekali didengarkan mengenai segala perasaan dan pikiran yang timbul dalam batinnya. melalui wawancara bimbingan konseling sangat bermanfaat bagi siswa dan mungkin merupakan satu-satunya kesempatan untuk berbicara secara terbuka.

Keadaan ini menuntut keaktifan siswa dalam memanfaatkan layanan bimbingan konseling dan menggeser persepsi negatif siswa tentang layanan bimbingan konseling. persepsi yang selama ini timbul bahwa layanan bimbingan konseling hanya diperuntukkan bagi siswa siswa yang dipanggil oleh guru bidang studi, layanan bimbingan konseling identik dengan usaha mendisiplinkan siswa, pemberian nasihat, serta identik dengan usaha penyembuan penyakit jiwa. Sehinga siswa khawatir akan sindiran teman karena berpenyakit stress, juga siswa takut menghadapi konselor, serta siswa kurang percaya kepada konselor dalam menghadapi persoalan yang bersifat pribadi, karena takut rahasianya akan terbongkar.

Jadi persepsi siswa terhadap layanan bimbingan konseling adalah suatu proses diterimanya rangsang oleh siswa berupa informasi mengenai layanan bimbingan konseling sehingga siswa dapat menyimpulkan informasi dan menafsirkan pesan

\section{METODE PENELITIAN}

Penelitian ini dilaksanakan di MTs Negeri III Surabaya, khususnya di kelas VII D yang merupakan tempat pelaksanaan kegiatan penelitian. Mengingat permasalahan yang ada di lokasi penelitian cukup 
kompleks dan tentunya tidak dapat diteliti secara sekaligus, karena itu penelitian ini difokuskan pada peserta didik kelas VII D yang masih rendah persepsinya terhadap peran BK. Hasil perubahan persepsi ini dilihat dari keinginan peserta didik untuk menemui guru BK

Adapun sumber data dalam penelitian ini adalah dokumen rekaman buku tamu siswa yang datang secara sukarela ke ruang BK dan surat yang dikirim siswa di kotak masalah.

Penelitian yang menggunakan objek penelitian adalah semua siswasiswi kelas VII D di MTs Negeri III Surabaya ini dilakukan dalam jangka waktu empat bulan yaitu antara Bulan Januari s/d bulan April 2016.

Rincian kegiatan dan jadwal kegiatan dapat di lihat pada tabel berikut ini :

\section{Rincian dan jadwal kegiatan}

\begin{tabular}{|c|c|c|c|c|c|c|c|c|c|c|c|c|c|c|c|c|}
\hline \multirow{2}{*}{$\begin{array}{l}N \\
O\end{array}$} & \multirow{2}{*}{ KEGIATAN } & \multicolumn{4}{|c|}{ JANUARI } & \multicolumn{4}{|c|}{ PEBRUARI } & \multicolumn{5}{|c|}{ MARET } & \multicolumn{2}{|c|}{ APRIL } \\
\hline & & 1 & 2 & 3 & 4 & 1 & 2 & 3 & 4 & 1 & 2 & 3 & 4 & 5 & 1 & 2 \\
\hline$A$ & Persiapan & & & & & & & & & & & & & & & \\
\hline 1 & $\begin{array}{l}\text { Informasi / data } \\
\text { siswa yang datang } \\
\text { ke ruang BK }\end{array}$ & V & & & & & & & & & & & & & & \\
\hline 2 & $\begin{array}{l}\text { Identifikasi } \\
\text { Masalah/ Kajian } \\
\text { obyektif lapangan }\end{array}$ & & V & & & & & & & & & & & & & \\
\hline 3 & $\begin{array}{l}\text { Menyusun } \\
\text { Proposal/ } \\
\text { Merancang PTK }\end{array}$ & & & V & & & & & & & & & & & & \\
\hline 4 & $\begin{array}{l}\text { Menyusun } \\
\text { Instrument }\end{array}$ & & & & V & & & & & & & & & & & \\
\hline$B$ & Pelaksanaan & & & & & & & & & & & & & & & \\
\hline 1 & $\begin{array}{l}\text { Layanan } \\
\text { bimbingan } \\
\text { kelompok }\end{array}$ & & & & & V & V & V & V & & & & & & & \\
\hline 2 & Evaluasi & & & & & & & & & V & & & & & & \\
\hline 3 & Perbaikan & & & & & & & & & & $\mathrm{V}$ & V & $\mathrm{V}$ & $\mathrm{V}$ & & \\
\hline C & $\begin{array}{l}\text { Penyusunan } \\
\text { laporan }\end{array}$ & & & & & & & & & & & & & & & \\
\hline 1 & Menyusun laporan & & & & & & & & & & & & & & V & V \\
\hline
\end{tabular}

Penelitian ini mengandung tindakan yaitu mengubah persepsi negatif siswa terhadap layanan bimbingan konseling sekolah. Oleh karena itu, penilitian ini termasuk jenis penelitian tindakan. Selain itu, penelitian ini menggunakan latar alamiah, analisis datanya bersifat 
induktif-deskriptif, menggunakan manusia sebagai instrumen kunci, dan memperhatikan proses daripada hasil. Berdasarkan ciri-ciri tersebut, penelitian ini termasuk penelitian yang menggunakan pendekatan kualitatif (Bogdan dan Biklen, 1992).

\section{Teknik Pengumpulan data}

Data penelitian dikumpulkan dengan menggunakan catatan lapangan, observasi, wawancara, dan dokumentasi.

(a) Catatan lapangan

Catatan lapangan merupakan teknik pengumpulan data yang paling praktis dan mudah dilaksanakan kapan saja dan di mana saja. Pencatatan ini dilakukan untuk mencatat aktivitasaktivitas sosialisasi, diskusi dan kegiatan-kegitan yang lain.

(b) Observasi

Observasi dilakukan untuk mengamati aktivitas siswa sehari-hari serta kebiasaan-kebiasaan siswa selama jam istirahat.

(c) Diskusi

Diskusi yang sering dilakukan dalam kelompok-kelompok siswa, bahan yang didiskusikan dapat dijadikan masukan untuk penelitian ini. (d) Wawancara

Wawancara digunakan untuk memperkuat dan melengkapi data yang diperoleh dari observasi.

(e) Data Dokumentasi

Data dokumentasi merupakan catatan-catatan yang ada di BK sekolah, data ini sangat diperlukan sebagai pelengkap bahkan pembanding dengan data yang baru diperoleh.

\section{Hasil Penelitian dan Pembahasan}

Alur kegiatan mencari dan menyusun jawaban pertanyaan penelitian adalah sebagai berikut :

Peneliti melakukan

\section{Perencaaan siklus ke 1}

Yaitu merencanakan strategi pendekatan kepada siswa

Pada tahap ini peneliti merencanakan strategi pendekatan kepada siswa dengan menggunakan layanan bimbingan kelompok.

- Menyusun rencana tindakan siklus ke 1

Peneliti setelah merencanakan strategi deengan layanan bimbingan kelompok, peneliti merencanakan untuk mendatangi kerumunan siswa pada setiap kesempatan baik pada saat 
sebelum bel masuk ataupun pada saat istirahat baik istirahat ke 1 maupun istirahat ke 2

- Menyusun skenario pendekatan kepada siswa

Setiap ada sekumpulan siswa peneliti akan ikut membaur dengan mereka dan ikut bercerita tentang hal-hal yang menarik bagi mereka.

2. Pelaksanaan siklus ke 1 dan

3. Pengamatan siklus ke 1

Pada tahap ini peneliti setiap sebelum bel masuk atau waktu istirahat mendatangi kerumunan siswa baik yang ada di dalam kelas maupun diluar kelas untuk menunjukkan atau menggambarkan kepada siswa bahwa guru BK itu bukan sesuatu yang menakutkan tapi dengan berhubungan dengan guru BK itu menjadi sesuatu yang menyenangkan dan akan lebih menyenangkan lagi jika bisa berkomunikasi secara langsung di ruang $\mathrm{BK}$

Tahap pendekatan melalui :

- Mendatangi masing-masing kelas.

- Menceritakan permasalahanpermasalahan yang mungkin terjadi pada siswa dan kemungkinan pemecahannya

- Menjelaskan peran layangan bimbingan konseling sekolah

4. Refleksi siklus ke 1

Dari hasil siklus yang ke 1 ternyata hasilnya belum memenuhi target dimana siswa yang datang ke ruang BK selama bulan Pebruari ada 4 siswa kelas VII D yang datang ke ruang $\mathrm{BK}$ dan ada 4 siswa yang berkirim surat serta ada 4 siswa dari kelas lain yang datang ke ruang BK, sedangkan targetnya minimal $50 \%$ dari jumlah siswa kelas VII D.Oleh karena belum mencapai target maka perlu dilakukan siklus yang ke 2

1. Perencanaan siklus ke 2

Pada tahap ini peneliti
merencanakan strategi
pendekatan kepada siswa
dengan menggunakan layanan
bimbingan kelompok.
Peneliti setelah merencanakan
strategi deengan layanan
bimbingan kelompok, peneliti
merencanakan untuk
mendatangi kerumunan siswa
pada setiap kesempatan baik
pada saat sebelum bel masuk


ataupun pada saat istirahat baik istirahat ke 1 maupun istirahat ke 2 secara lebih intensif.

- Menyusun skenario

pendekatan kepada siswa

Setiap ada sekumpulan siswa peneliti akan ikut membaur dengan mereka dan ikut bercerita tentang hal-hal yang menarik bagi mereka.

2. Pelaksanaan siklus ke 2 dan

3. Pengamatan siklus ke 2 Pada tahap ini peneliti setiap sebelum bel masuk atau waktu istirahat mendatangi kerumunan siswa baik yang ada di dalam kelas maupun diluar kelas dengan lebih intensif untuk menunjukkan atau menggambarkan kepada siswa bahwa guru BK itu bukan sesuatu yang menakutkan tapi dengan berhubungan dengan guru BK itu menjadi sesuatu yang menyenangkan dan akan lebih menyenangkan lagi jika bisa berkomunikasi secara langsung di ruang BK

Tahap pendekatan melalui :

- Mendatangi masing-masing kelas.dengan lebih intensif
- Menceritakan permasalahanpermasalahan yang mungkin terjadi pada siswa dan kemungkinan pemecahannya

- Menjelaskan peran layangan bimbingan konseling sekolah

- Mengajak bergurau dan makan bersama

- Bersikap seperti teman

4. Refleksi siklus ke 2

Dari hasil siklus yang ke 2 ternyata hasilnya memenuhi target dimana siswa yang datang ke ruang $\mathrm{BK}$ selama bulan Pebruari ada 4 siswa kelas VII D yang datang ke ruang $B K$ dan ada 4 siswa yang berkirim surat serta ada 4 siswa dari kelas lain yang datang ke ruang $\mathrm{BK}$, dan di bulan maret ada 25 siswa kelas VII D yang datang ke ruang BK dan ada 29 siswa yang berkirim surat serta ada 45 siswa yang datang ke ruang $\mathrm{BK}$ sedangkan targetnya minimal $50 \%$ dari jumlah siswa kelas VII D $(50 \%$ x 36 siswa $=$ 18 siswa).Oleh karena sudah mencapai target maka perlu ditingkatkan lagi 
Data Siswa Kelas VII-D Yang Datang Ke Ruang BK Dan Yang Berkirim Surat

$\mathrm{Ke} \mathrm{BK}$

\begin{tabular}{|l|l|c|lr|l|}
\hline NO & BULAN & $\begin{array}{l}\text { JUMLAH SISWA } \\
\text { YANG DATANG KE } \\
\text { RUANG BK }\end{array}$ & $\begin{array}{l}\text { JUMLAH SISWA } \\
\text { YANG CURHAT } \\
\text { LEWAT SURAT }\end{array}$ & $\begin{array}{l}\text { JUMLAH } \\
\text { YANG SISWA } \\
\text { SELAIN KELAS VII D }\end{array}$ \\
\hline 1 & Januari & 0 & 0 & 0 \\
\hline 2 & Pebruari & 4 & 4 & 4 \\
\hline 3 & Maret & 25 & 29 & 45 \\
\hline
\end{tabular}

Dengan adanya peningkatan jumlah siswa yang datang ke ruang BK tanpa ada panggilan maka hal itu menunjukkan adanya perubahan persepsi (persepsi negatif menjadi persepsi positif). Hal ini sesuai dengan tujuan layanan bimbingan dan konseling.

\section{DAFTAR PUSTAKA}

Abror, Abdul Rahman. (1993). Psikologi Pendidikan. Yogyakarta : PT Tiara Wacana.

Bungin,Burhan.(2001). Metodologi Penelitian Sosial, Surabaya: Penerbit Airlangga University Press.

Irwanto, Drs. (2002). Psikologi Umum. Jakarta : PT Prenhallindo.

Faisal,Sanapiah.(1995). Formatformat Penelitian Sosial, Jakarta: PT.Rajawali Grafindo Persada, cetakan ke-3.

Gunarsa,Singgih D dan Ny. Singgih D Gunarsa.(1998). Bimbingan Konseling, Jakarta: PT.BPK Gunung Mulia, 1988.
Hamalik,Oemar.(2002). Psikologi Belajar dan Mengajar, Bandung : Penerbit Sinar Baru Algensindo.

Hurlock,Elizabeth.(1997) Psikologi Perkembangan, Jakarta: Penerbit Erlangga.

Kartono, Kartini.(1986). Patologi Sosial 2: Kenakalan Remaja , Jakarta: CV. Rajawali, cetakan pertama, Desember.

Latipun. (2001). Psikologi Konseling. Malang : Universitas Muhammadiah .

Mapiere, Andi. (1984). Pengantar Bimbingan Dan Konseling Disekolah. Surabaya : Usaha Nasional.

Muawanah, Kholisotul (2004). Studi Deskripsi Tentang PermasalahanPermasalahan Siswa SMU Negeri di Surabaya. Skripsi, Universitas Putra Bangsa Surabaya.

Nasir, M (1988). Metodologi Penelitian. Jakarta : Raja Grafindo Perkasa.

Natawidjaja,Rochman.(1987).

Pendekatan-pendekatan dalam Penyuluhan Kelompok I, Bandung: Penerbit CV. Diponegoro. 
46 - Helper, Vol 34 No 2 (2017)

Naqiyah, Najlatun,Dr (2012). Bidang Layanan Bimbingan dan Konseling. Surabaya : UNESA

Prayitno,dan Erman Amti.(1999).

Dasar-dasar Bimbingan dan

Konseling, Jakarta: Penerbit Rineka

Cipta.

Rahkmat Jalaluddin. (1999) Psikologi Komunikasi. Bandung : PT. Remaja Rosda Karya.

Sukardi DK, Drs. (1988). Bimbingan dan konseling. Jakarta. Bina Aksara.

Sukardi,Dewa Ketut.(2000). Pengantar Pelaksanaan Program Bimbingan dan Konseling di sekolah, Jakarta: Penerbit Rineka Cipta. 